\title{
Synchronous Bilateral Acinic Cell Carcinoma of the Parotid
}

\author{
Sourav Guha*, Rajdeep Guha, Kapila Manikantan, Rajeev Sharan, Pattatheyil Arun, Indranil Mallick and Sanjoy Chatterjee \\ Tata Medical Center, Kolkata, India
}

Sir,

Acinic cell carcinoma is a rare parotid malignancy and constitute approximately $3 \%$ of all parotid tumors [1]. However though bilateral parotid salivary gland tumors are extremely uncommon bilateral acinic cell carcinoma may not be so rare and constitute $3 \%$ of all acinic cell carcinomas. There are limited data on the incidence of bilateral acinic cell carcinoma which have been treated over the years [3-6].

A $50 \mathrm{yr}$ old female from Bhutan presented on January 2012 with chief complaints of swelling over right infra auricular region of one month duration. She was initially investigated in Bhutan with a Fine Needle Aspiration Cytology (FNAC) that was reported as acinic cell carcinoma of the right parotid gland. She visited our centre for further treatment option.

On examination there was a $3 \times 2.5 \mathrm{~cm}$ firm to hard swelling over the right infra auricular region and also a small nodular swelling measuring $1 \times 1 \mathrm{~cm}$ in the left parotid gland. There was no facial weakness. Laryngeal scope examination revealed adequate airway with a small hemangioma over the right base of the tongue. No neck nodes were palpable. Slide review at our centre was called out as acinic cell carcinoma.

Maxillofacial MRI revealed a well defined and lobulated space occupying lesion measuring $2.7 \times 2.5 \times 1.6 \mathrm{~cm}$ in right superficial parotid gland which was predominantly hypointense on T2W1 and hyperintense on Short TI Inversion Recovery (STIR) sequences. Marginal extension to deep part of parotid lobe was observed. The lesion was closely abutting retromandibular vein. On the left another enhancing space occupying lesion (SOL) measuring $2.1 \times 1.6 \times 1 \mathrm{~cm}$ seen within the superficial parotid gland with pockets of hyperintense foci within the hypointense mass on long triplet repeat (TR) sequences. The deep lobe was free; small nodes seen at level I. Bilateral level II nodes noted largest measuring $1.6 \times 0.6 \mathrm{cms}$. FNAC from left parotid gland was done and reported as neoplastic cells present, basaloid neoplasm. Chest $\mathrm{X}$-ray and blood investigations including complete blood count, renal function test and liver function tests were within normal limits. Patient underwent bilateral total conservative parotidectomy with bilateral level II neck dissection. Histopathology report was called out as Acinic cell carcinoma involving the superficial lobe of right parotid gland and deep lobe of the left parotid gland. The tumor in its greatest dimension measured $2.4 \mathrm{~cm}$ on the right side and $3 \mathrm{~cm}$ on left side. Perineural invasion was present in both the sides [7]. Level II and intraparotid lymph nodes were negative for malignancy and all the margins were reported to be free of tumor. Post surgery she was treated with external beam radiotherapy to bilateral tumor bed on tomotherapy to a dose of $60 \mathrm{~Gy}$ in conventional fractionation (Figure 1 and 2).

Salivary gland tumors comprises of approximately $4 \%$ of all head and neck tumors of which almost $80 \%$ are parotid gland tumors. Bilateral parotid gland neoplasm is uncommon and bilateral synchronous parotid gland tumors are extremely rare $[8,9]$. Acinic cell carcinoma of parotid account for approximately $5 \%$ of all salivary gland neoplasms and have the best prognosis with a 10 -year relative survival of $88 \%$ [1]. Typical clinical feature includes a slowly growing mass in the parotid gland area. They are low grade tumors without frequent involvement of the facial nerve. Mean age of diagnosis is 44 years with a $\mathrm{M}: \mathrm{F}=2: 3$. Although these tumors rarely metastasizes occasional late distant metastases have been reported.

We searched for published articles in peer reviewed journals using two search engines: Pubmed - (Medline - The National Library of Medicine) and the Cochrane library. The specified search criteria included: "Bilateral parotid tumor", "Bilateral acinic cell tumor" and

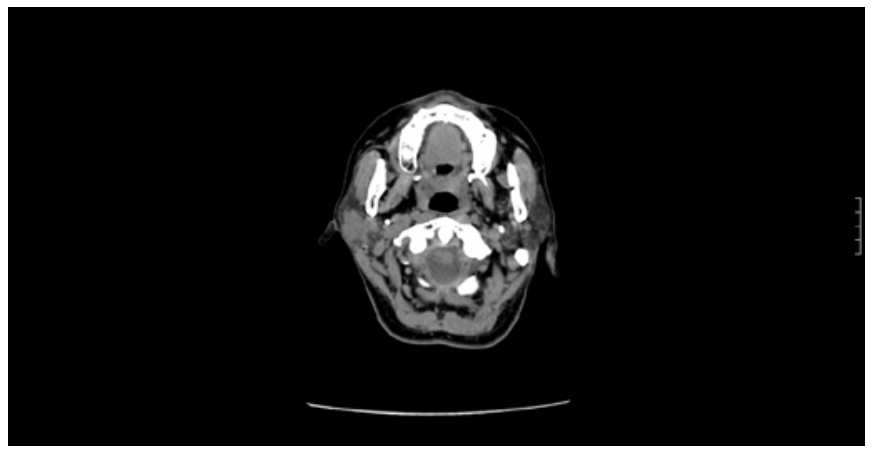

Figure 1: Maxillofacial MRI showing space occupying lesion within the superficial lobe of the parotid gland.

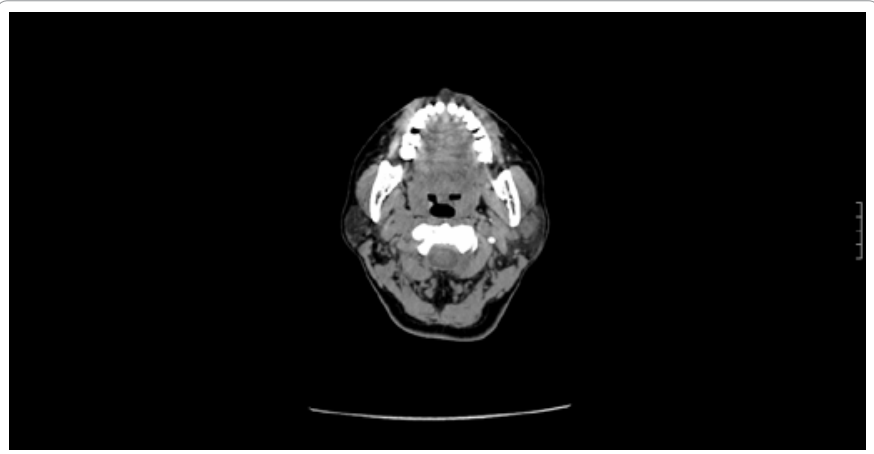

Figure 2: Maxillofacial MRI showing space occupying lesion within the superficial lobe of the right parotid gland with extension to the deep lobe of the parotid gland.

*Corresponding author: Dr. Sourav Guha, MD, Radiation Oncologist, Tata Medical Center, Kolkata, India, Tel: 09903156562; E-mail: drsouravguha@yahoo.com

Received March 22, 2012; Accepted April 23, 2012; Published April 25, 2012

Citation: Guha S, Guha R, Manikantan K, Sharan R, Arun P, et al. (2012) Synchronous Bilateral Acinic Cell Carcinoma of the Parotid. J Cancer Sci Ther 4: 092-093. doi:10.4172/1948-5956.1000118

Copyright: () 2012 Guha S, et al. This is an open-access article distributed under the terms of the Creative Commons Attribution License, which permits unrestricted use, distribution, and reproduction in any medium, provided the original author and source are credited. 
Citation: Guha S, Guha R, Manikantan K, Sharan R, Arun P, et al. (2012) Synchronous Bilateral Acinic Cell Carcinoma of the Parotid. J Cancer Sci Ther 4: 092-093. doi:10.4172/1948-5956.1000118

"Carcinoma of the parotid and submandibular glands". The review of literature showed majority of synchronous bilateral parotid malignancies are Acinic cell carcinoma. Bilateral acinic cell carcinoma can be either synchronous or asynchronous and till date only six cases of synchronous bilateral acinic cell carcinoma have been reported in medical literature which have been treated over the years [3-6,9]. To the best of our knowledge we hereby present the seventh case of synchronous bilateral acinic cell carcinoma of the parotid gland.

\section{References}

1. Eneroth CM, Jakobsson PA, Blanck C (1966) Acinic cell carcinoma of the parotid gland. Cancer 19: 1761-1772.

2. Wahlberg P, Anderson H, Biörklund A, Möller T, Perfekt R (2002) Carcinoma of the parotid and submandibular glands--a study of survival in 2465 patients. Oral Oncol 38: 706-713.

3. Clarke JS, Hentz EC, Mahoney WD (1969) Bilateral acinic cell carcinoma of the parotid gland. Ann Surg 170: 866-869.
4. Betkowski A, Cyran-Rymarz A, Domka W (1998) Bilateral acinar cell carcinoma of the parotid gland. Otolaryngol Pol 52: 101-104.

5. Bauer WH, Bauer JD (1953) Classification of glandular tumors of salivary glands; study of one-hundred forty-three cases. AMA Arch Pathol 55: 328-346.

6. Nelson DW, Nichols RD, Fine G (1978) Bilateral acinous cell tumors of the parotid gland. Laryngoscope 88: 1935-1941.

7. Levin JM, Robinson DW, Lin F (1975) Acinic cell carcinoma: collective review, including bilateral cases. Arch Surg 110: 64-68.

8. van Tongeren J, Creytens DH, Meulemans EV, de Bondt RB, de Jong J, et al (2009) Synchronous bilateral epithelial-myoepithelial carcinoma of the parotid gland: case report and review of the literature. Eur Arch Otorhinolaryngol 266 1495-1500.

9. Delides A, Velegrakis G, Kontogeorgos G, Karagianni E, Nakas D, et al. (2005) Familial bilateral acinic cell carcinoma of the parotid synchronous with pituitary adenoma: case report. Head Neck 27: 825-828. 